\title{
Spatiotemporal spread of huanglongbing in commercial citrus orchards of Minas Gerais, Brazil
}

\author{
Kaique S. Alves ${ }^{1} \bullet$ Leonardo H. M. do Carmo $^{2}$ • Emerson M. Del Ponte ${ }^{1}$ \\ ${ }^{1}$ Departamento de Fitopatologia, Universidade Federal de Viçosa, 36570-900, Viçosa, MG, Brazil. \\ ${ }^{2}$ Instituto Mineiro de Agropecuária, 30150-100, Belo Horizonte, MG, Brazil \\ Data and code for reproducibility are available at https://osf.io/23ghm \\ E. M. Del Ponte delponte@ufv.br
}

The spatiotemporal spread of citrus huanglongbing (HLB, ex greening) in Minas Gerais (MG) state, Brazil, was analyzed since its first detection in 2005. Data on the amount of eradicated plants per orchard were gathered from the georeferenced database of the state's official HLB monitoring program. In total, 1,487 orchards (118 municipalities) have been inspected yearly up to 2018 . Overall, $57.2 \%$ ( $64.4 \%$ of the municipalities) of the orchards were affected by HLB and a total of 459,254 plants, mainly mandarins (62.7\%) and sweet oranges (35.6\%), and very few lemon and acid lime (1.7\%), have been eradicated. The percent of HLB-affected orchards was variable in three scenarios of citrus varieties and citrus-growing regions: $20 \%$ of sweet orange orchards in the Triângulo Mineiro (TM) region and 64.8\% in the South of Minas (SM) region; and $80 \%$ of mandarins produced in the SM and $40.4 \%$ in the Central regions. The numbers of eradications were generally higher in mandarins in the SM than in sweet oranges in the TM because of the large orchard size, better management, and more recent introduction of the disease. HLB spread faster among orchards in the SM and Central regions due to a lack of HLB-oriented management, small size and proximity between each other. The disease has spread $45.9 \mathrm{~km} /$ year and $25.7 \mathrm{~km} /$ year on average in the TM and Central/SM, respectively. The HLB-affected orchards were spatially aggregated in mandarin orchards in the SM, which was not evident in sweet oranges growing the TM and SM. Research and extension resources shall be mobilized to help citrus farmers of the SM and Central regions to extend as much as possible the feasibility of the production and prevent further spread among and within mandarin orchards in Central MG. These results can be of value to further improve risk assessment of HLB spread in other regions that share similarities with those in MG state.

Keywords: Candidatus Liberibacter asiaticus, Diaphorina citri, Asian citrus psyllid, greening, rouging

\section{Introduction}

Citrus Huanglongbing (HLB), formerly greening, is the most destructive disease in the citrus-growing regions worldwide including Brazil, United States, and China (Bassanezi et al., 2020; Graham et al., 2020; Zhou et al. 2020). Three bacteria have been associated with HLB: Candidatus Liberibacter asiaticus, $\mathrm{Ca}$. Liberibacter americanus, and $\mathrm{Ca}$. Liberibacter africanus. The disease is spread mainly via psyllids, the known vector of the bacteria.
The Asian and American forms of the bacteria are vectored by Diaphorina citri (Hall et al. 2012), while the African form is vectored by Trioza erytreae, endemic to the African continent and recently found in Europe (Cocuzza et al. 2017). In addition to psyllids, the transmission may occur via grafting of infected propagative material (Coletta-Filho et al., 2010).

In Brazil, HLB was first detected in São Paulo (SP) state, in March 2004, the largest commercial citrus-growing region in South America (Coletta-Filho et al. 2004; Teixeira et al. 2005). Since then, the disease spread throughout all citrus regions in SP and later to other neighboring states including Minas Gerais in 2005, Paraná in 2007, and Mato Grosso do Sul in 2019 (Bassanezi et al. 2020). The introduction of HLB into SP state added to the constant challenge of managing multiple yield-damaging diseases of citrus to keep up with productivity, quality, and competitiveness (Erpen et al. 2018). In spite of research advances during the last decade and management for disease control, HLB did not cease spreading. In 2019, HLB incidence in the field averaged $19 \%$ in the SP citrus belt, which corresponded to 37.1 million trees, a $4.8 \%$ increase relative to the previous year (Bassanezi et al., 2020).

While genetic resistance remains a long-term solution and several non-chemical treatments, although effective in experimental conditions, are not deemed profitable at a large scale. Nevertheless, sequential insecticide spraying targeting the psyllids is the most used tool in the HLB management toolbox, but with various levels of success (see reviews by Bassanezi et al. 2020 and Graham et al. 2020). In an effort to slow down HLB spread, legislative control (via Instrução Normativa, IN) was first established by the IN10 in 2005, which was further replaced by IN32 in 2006 and IN53 in 2009 (Ruiz et al. 2010). State agencies became responsible for monitoring and reporting all newly confirmed cases and law-enforcing eradication of the entire orchard if the incidence of symptomatic trees reaches the $28 \%$ threshold (Belasque Jr et al. 2009). Collectively, these efforts have made it possible to manage the disease economically in Brazil, but the most effective control has been achieved 
using a wide-area management approach (Bassanezi et al. 2013). In this system, all farmers should act cooperatively, especially to avoid vector populations rising on their own orchards and backyard or forgotten citrus plants in the neighborhood (Bassanezi et al. 2013; Bassanezi et al. 2020).

HLB is a typical vector-borne polycyclic disease for which both the primary and secondary inoculum are dispersed during periods of vector activity. Hence, knowledge about insect flight patterns may provide insights into HLB spread. In general, the psyllid tends to disperse more locally, from plant to plant at distances from 30 to $100 \mathrm{~m}$, that usually peak during the spring season, although long-distance dispersal is also possible via repeated short-distance flights (Boina et al., 2009; Hall and Hentz. 2011; Hall et al. 2012).

The spatial aspects of HLB spread have been studied since its discovery in Asia and the Americas, but the majority of the work used data at the orchard rather than the region scale. In general, these studies show that HLB is rarely randomly distributed in the field, as the initial foci tend to expand from the edge of the orchards where psyllid first reaches the plants (Bassanezi et al. 2005; Gottwald et al. 2010; Leal et al. 2010; Parnell et al. 2011; Shen et al. 2013; Gasparoto et al., 2018). Analysis of the empirical disease observations and outputs of mechanistic models that simulate temporal and/or spatial spread have been useful to test hypotheses on how to best manage HLB (Craig et al. 2018; Lee et al. 2015; Parry et al. 2014). At the regional scale, authors of studies conducted in Mexico and in Florida have gathered and analyzed data to study gradients, patterns, and the rate of frontal movement of the epidemics (Flores-Sánchez et al. 2017; Shimwela et al. 2018).

Table 1: Summary statistics for commercial citrus varieties grown in three production regions of Minas Gerais state determined based on reports of in-field inspections and eradication due to the detection of huanglongbing conducted during a 14-year (2005 to 2018) period. Data was collected by field inspectors supervised by the Instituto Mineiro de Agropecuária, Minas Gerais State, Brazil.

\begin{tabular}{|c|c|c|c|c|c|c|}
\hline \multirow[b]{2}{*}{ Region } & \multirow[b]{2}{*}{ Citrus variety } & \multicolumn{3}{|c|}{ Orchards } & \multicolumn{2}{|c|}{ Plants } \\
\hline & & Total count & Mean area (ha) & HLB-affected (\%) & Total count & Eradication (\%) \\
\hline \multirow{5}{*}{$\begin{array}{l}\text { Triângulo } \\
\text { Mineiro }\end{array}$} & Acid-lime & 21 & 13.04 & 4.76 & 152,635 & 0.02 \\
\hline & Lemon & 1 & 15.10 & 0 & 5,300 & - \\
\hline & Sweet orange & 173 & 183.84 & 20.23 & $15,713,610$ & 0.36 \\
\hline & Mandarin & 16 & 28.95 & 31.25 & 190,174 & 3.28 \\
\hline & All types & 211 & 154.29 & 19.43 & $16,061,719$ & 0.39 \\
\hline \multirow{5}{*}{$\begin{array}{l}\text { South of } \\
\text { Minas }\end{array}$} & Acid-lime & 22 & 37.01 & 40.91 & 341,291 & 1.91 \\
\hline & Lemon & 6 & 5.55 & 16.67 & 8,605 & 10.51 \\
\hline & Sweet orange & 107 & 49.95 & 67.29 & $3,103,464$ & 3.41 \\
\hline & Mandarin & 666 & 8.76 & 79.28 & $3,178,061$ & 8.42 \\
\hline & All types & 801 & 15.02 & 76.15 & $6,631,421$ & 5.75 \\
\hline \multirow[t]{4}{*}{ Central } & Acid-lime & 2 & 6.75 & 0 & 7,425 & 0 \\
\hline & Sweet orange & 4 & 66.99 & 25 & 184,626 & 0.51 \\
\hline & Mandarin & 469 & 11.88 & 42.43 & $2,868,645$ & 0.61 \\
\hline & All types & 475 & 12.32 & 42.11 & $3,060,696$ & 0.60 \\
\hline $\begin{array}{l}\text { All } \\
\text { regions }\end{array}$ & All types & 1487 & 33.92 & 57.23 & $25,753,836$ & 1.78 \\
\hline
\end{tabular}


In Brazil, Minas Gerais (MG) is the second largest citrus-producing state. Promptly after the disease was first reported in MG in 2005, the plant health state agency implemented a monitoring and eradication program. Every single year, commercial orchards in municipalities neighboring other ones where the disease was present has been inspected and plants exhibiting symptoms that resemble HLB are tested for the presence of HLB pathogen and eradicated when confirmed positive. These data were analyzed in this study to provide the first comprehensive summary of the spatiotemporal spread of HLB in MG state. We hypothesize that region, management, and species-specific features affect the rates of the spatial-temporal spread of HLB. These results may be useful to provide insights into the disease epidemiology as well as to inform decision-makers on how to best deploy resources for further monitoring and assessing HLB risk in regions where it is still absent.

\section{Materials and Methods}

\section{Study area, sampling and data source}

The data used in this study have been gathered and organized by the Instituto Mineiro de Agropecuária (IMA), the state agency responsible for the HLB monitoring program initiated after the first HLB detection in 2005. During the first years, up to 2012, visits to the orchards have been made once a year and limited to those orchards where the disease has been previously detected. From 2013 onwards, the inspections were extended to all orchards in the municipality (risk area 1) as well as all neighboring municipalities (risk area 2). The frequency of visits increased to four per year, but the data are aggregated and reported to IMA at a six-month interval.

A

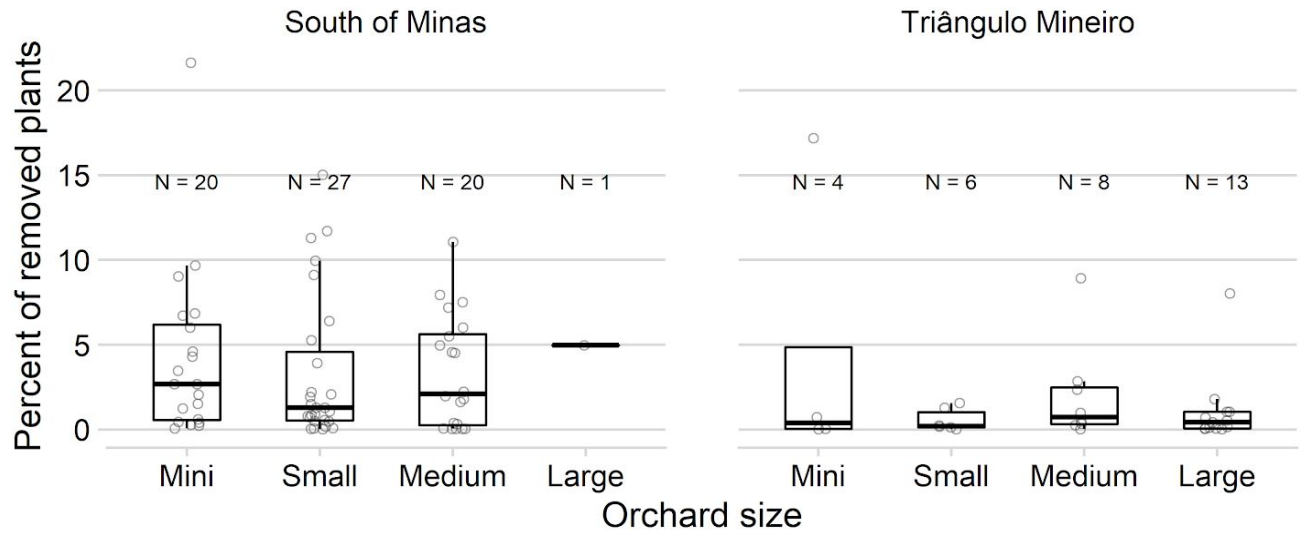

B

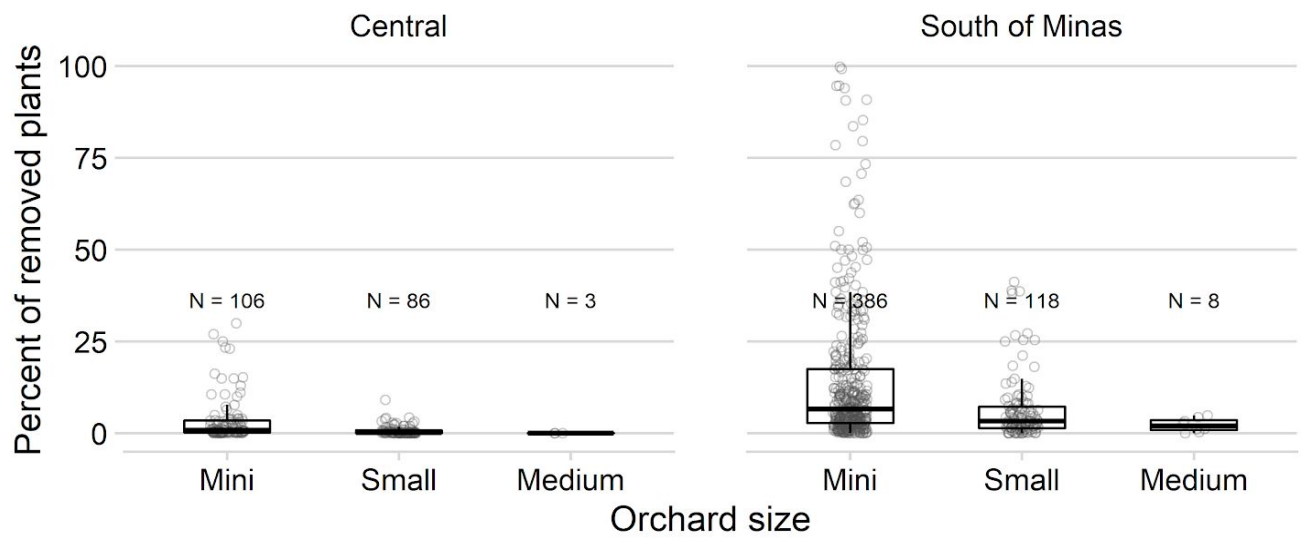

Figure 1: Percent of removed plants since the first detection of huanglongbing in commercial orchards of sweet orange (Citrus $x$ sinensis) (A) or mandarins (Citrus reticulata) (B) conditioned to citrus production region and the size of the orchard: Large: area $\geq 200$ ha; Medium: 50 ha < area $\leq 200$ ha, or Small: 10 ha < area $\leq 50$ ha, and; Mini: area $\geq 10$ ha. N represents the total number of orchards on each scenario. Data obtained from reports of in-field inspections conducted during a 14-year (2005 to 2018) period. 
During the inspection, trained assessors supervised by a certified agronomist walk through the entire orchard looking for symptoms. Once a suspected HLB-symptomatic plant is detected for the first time in an orchard, samples are sent to the laboratory for confirmation by PCR assays. The farmer is further notified and the record, whether negative (no symptoms or not confirmed) or positive, is added to the database. For the visits performed during the fruiting period, visual detection is facilitated on fruit, especially in mandarins that do not show the typical foliar symptoms that are more evident in sweet orange. The HLB-symptomatic trees are marked for eradication and counted during each visit.

\section{Orchard-specific data and variables}

As of October 2019, the official database contained 1,487 records including negative and positive detections.
The number of HLB-affected and eradicated plants per orchard was available for the year or semester since the first detection.

Other orchard-specific data included the total number of trees in the orchard, latitude and longitude, geographic region according to IMA's classification (South of Minas, Triângulo Mineiro and Central), citrus species (Citrus sinensis - sweet orange, C. reticulata - mandarins, C. latifolia - acid lime or C. limon - lemons), and orchard size (Large: area $\geq 200$ ha; Medium: 50 ha $<$ area $\leq 200$ ha, or Small: 10 ha < area $\leq 50$ ha, and; Mini: area $\leq 10$ ha). The final percentage of removed trees in the orchard, relative to total numbers in the orchard, was calculated for each year as well cumulative over the years.

Table 2: Total number of orchards, recorded during in-field inspections for the presence of huanglongbing conducted during a 14-year (2005 to 2018) period, summarized by each combination of citrus varieties (mandarins and sweet oranges), production regions in the state of Minas Gerais, Brazil (Triângulo Mineiro, South of Minas and Central) and citrus orchard size (Large: area $\geq 200$ ha; Medium: 50 ha < area $\leq 200$ ha, or Small: 10 ha < area $\leq 50$ ha, and; Mini: area $\leq 10$ ha).

Number of orchards

\begin{tabular}{|c|c|c|c|}
\hline \multirow[b]{2}{*}{ Production region } & \multirow[b]{2}{*}{ Orchard Size } & \\
\hline & & $\begin{array}{c}\text { Mandarin } \\
\text { (Citrus reticulata) }\end{array}$ & $\begin{array}{c}\text { Sweet orange } \\
\text { (Citrus } x \text { sinensis) }\end{array}$ \\
\hline \multirow[t]{5}{*}{ Triângulo Mineiro } & Mini & 7 & 28 \\
\hline & Small & 7 & 72 \\
\hline & Medium & 2 & 42 \\
\hline & Large & 0 & 31 \\
\hline & Sum & 16 & 173 \\
\hline \multirow[t]{5}{*}{ South of Minas } & Mini & 514 & 33 \\
\hline & Small & 137 & 45 \\
\hline & Medium & 15 & 26 \\
\hline & Large & 0 & 3 \\
\hline & Sum & 666 & 107 \\
\hline \multirow[t]{5}{*}{ Central } & Mini & 299 & 0 \\
\hline & Small & 159 & 2 \\
\hline & Medium & 11 & 2 \\
\hline & Large & 0 & 0 \\
\hline & Sum & 469 & 4 \\
\hline All regions & Sum & 1,151 & 284 \\
\hline
\end{tabular}




\section{Spatiotemporal regional spread of HLB}

Each orchard was considered either unaffected (no eradication) or affected (at least one eradicated plant). Progress curves for the cumulative number of HLB-affected orchards over the years and yearly maps were prepared to depict the temporal and spatial spread across the state.

\section{Spatial extent and rate of epidemic expansion}

The maximum spatial extent of the epidemics, defined as the largest distance between two HLB-affected orchards, were calculated for each year starting in 2008 when more than one case was reported. The degree decimal of the available latitude and longitude data for each orchard were converted into plane coordinates with a universal transverse Mercator (UTM) projection. The UTM coordinates were transformed into kilometers for obtaining the pairwise-distances between orchards.

Two initial foci were assumed as the entry point for the disease in the state, one at the South of Minas (2005) and another at the Triângulo Mineiro (2009), both bordering São Paulo State. Therefore, the yearly maximum distances were calculated separately for the Triângulo Mineiro region and the South of Minas and Central regions combined, given their proximity and continuity of citrus production.

The overall rate of expansion across the year was estimated from the fit of a generalized additive model (GAM) to the yearly maximum spatial extent for the two regions as defined. This model allows fitting a smooth curve through the data and thus accounting for the apparent nonlinear behavior. The gam() function of the mgcv package (wood 2017) of R (R Core Team 2018) was used for fitting the GAMs with the thin plate regression splines as smoothing basis function. The rates (trends) were calculated using the emtrends() function of the emmeans package (Lenth et al 2019) that calculates the averages for the marginal differences in the predicted curves.
A

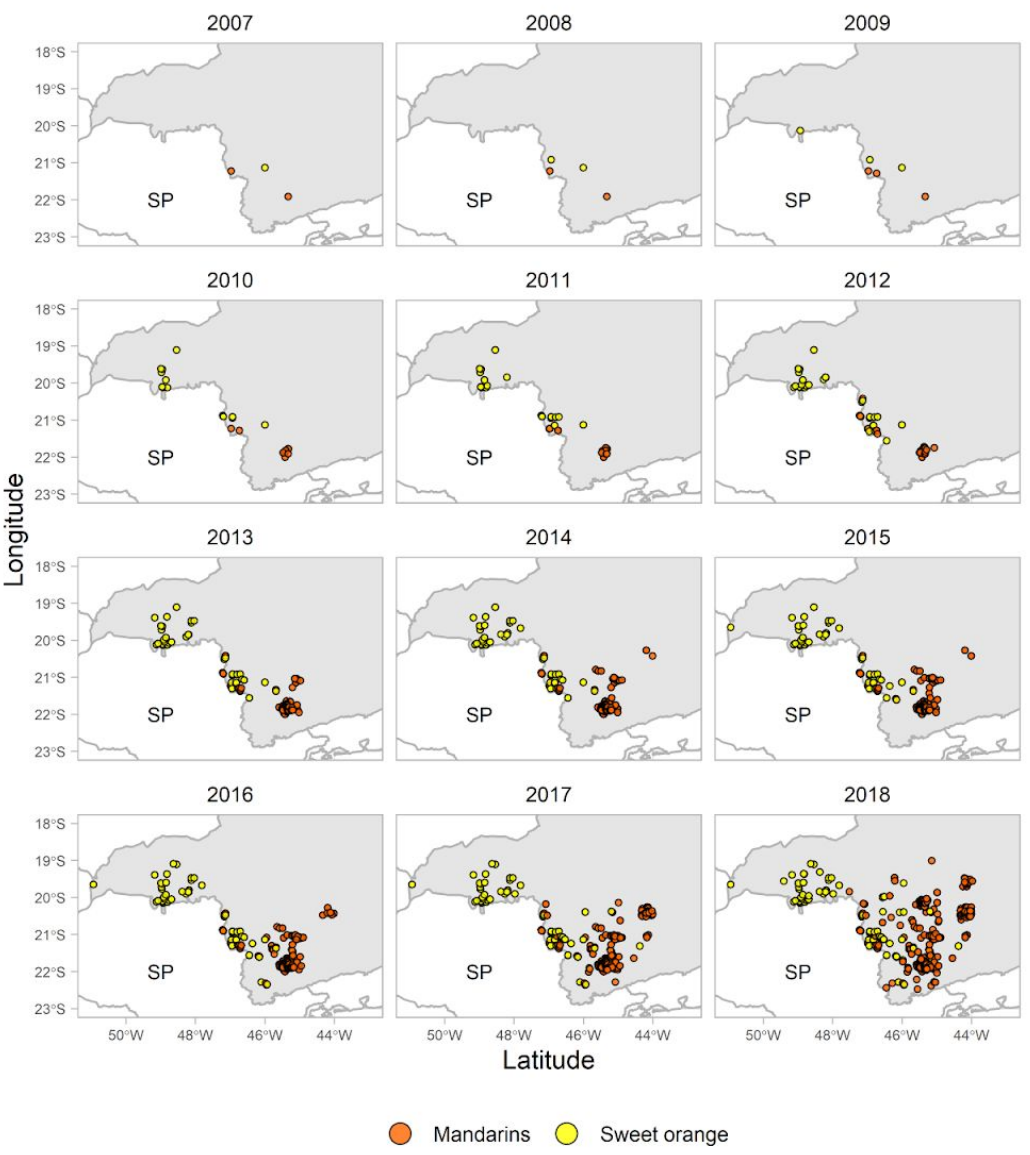

B

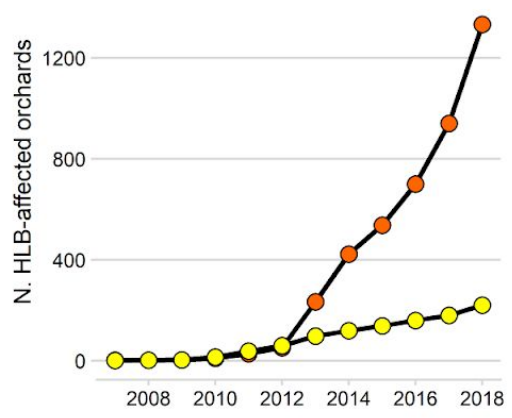

C

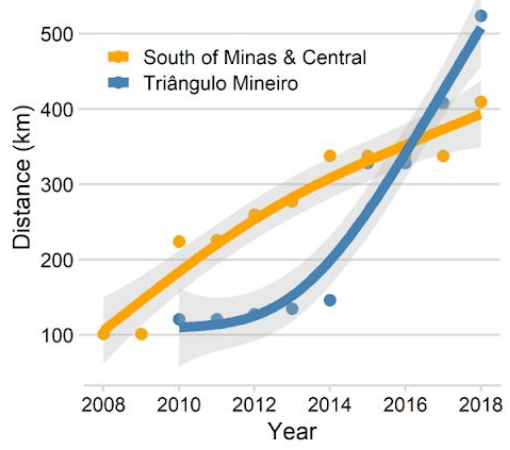

Figure 2: Yearly maps of huanglongbing (HLB) detection in individual orchards (A) and progress curves of the cumulative number of HLB-affected commercial orchards (B) of sweet orange (Citrus x sinensis) and mandarins (Citrus reticulata). The yearly maximal distance between two HLB-affected orchards was calculated separately to Triângulo Mineiro (blue dots) and South of Minas/Central regions combined (orange dots), assuming independent introductions (C). The smoothed lines are the predictions by a generalized additive model fitted for the yearly maximal distances 


\section{Nearest-neighbor distances}

The nearest-neighbor distances (NND) among pairs of HLB-affected orchards were calculated based on the assumption that the source of primary inoculum for an orchard originated most probably from the closest HLB-affected orchard. The NNDs were calculated for each semester of each year starting from 2013 when the reports were performed twice a year. The percent HLB-affected areas were grouped according to three scenarios defined based on the citrus variety and region: a) sweet orange in the Triângulo Mineiro; b) sweet orange in the South of Minas; and c) mandarins in both South of Minas and Central regions. The NND values were calculated using the nndist() function of spatstat (Baddeley et al. 2015) R package and presented in histograms for each scenario.

\section{Spatial point pattern analysis}

The O-ring statistics was used to detect the spatial pattern (randomness or aggregation) similar to a previous study of large-scale plant disease spread (Ojiambo and
Holmes 2010). The O-ring method is an alternative to the Ripley's cumulative K-function, but while in the the latter relates to cumulative points patterns within a circle, the $\mathrm{O}$-ring statistics is analogous to the cumulative K-function, but differs by a replacement of the circle with radius by a ring with radius (Wiegand and Moloney 2004), and is given by:

$$
O(r)=\lambda_{2} g_{12}(r),
$$

where $\lambda_{2}$ is the intensity and $g_{12}(r)$ mark-correlation function. Using rings instead of circles allows one to isolate specific distance classes, whereas the cumulative K-function confounds effects at larger distances with effects at shorter distances. Additional advantage of the $\mathrm{O}$-ring statistics is that it is a probability density function with the interpretation of a neighborhood density, which is more intuitive than a cumulative measure (Wiegand and Moloney 2004).
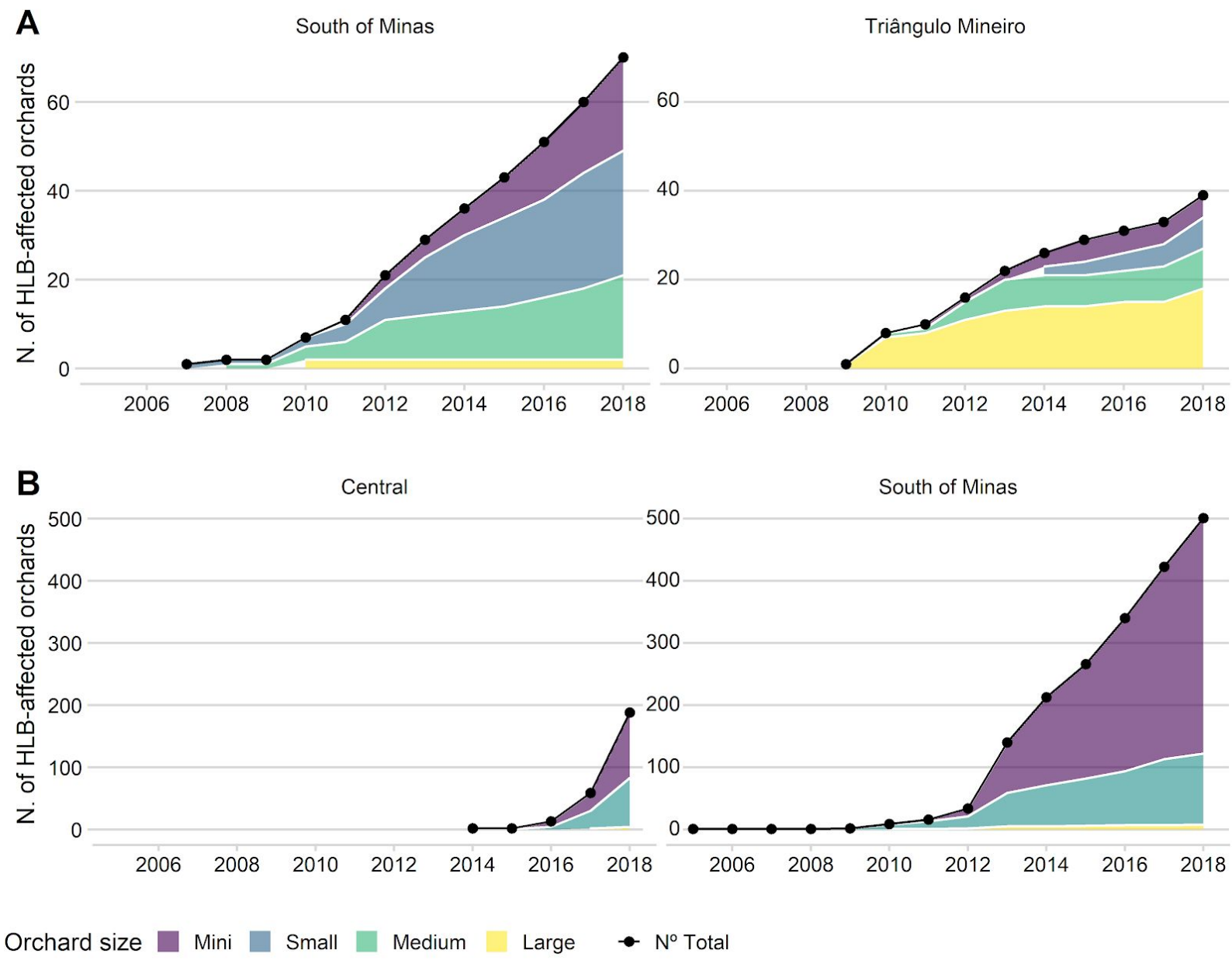

Figure 3: Cumulative yearly number of reports of HLB-affected orchards in sweet orange (A) and mandarins (B), each grown in two citrus-producing regions of the state. The areas represent the proportion of orchards colored by orchard size within the year. See table 2 for the total number of orchards per citrus type, region and orchard size. 
The null hypothesis (complete spatial randomness) was tested by running 999 Monte Carlo simulations of the null model and calculated the $95 \%$ credible interval. Values lying outside the credible interval indicate spatial aggregation at a given distance. The O-ring statistics were calculated for the final cumulative detections in 2018 separated for each of the three scenarios of production as described. We developed an $\mathrm{R}$ script that used functions available in the spatstat package (Baddeley et al. 2015).

\section{Data processing, availability, and reproducibility}

Exploratory analyses to prepare, transform, and visualize the data were performed using several $\mathrm{R}$ packages of the tidyverse, a "meta" package designed to make it easy to install and load a set of packages that share common data representations and API design (Wickham et al 2019). The fully annotated $\mathrm{R}$ scripts were prepared as $\mathrm{R}$ Markdown documents (Xie et al. 2018). All files (data, scripts, plots, etc.) were organized as a research compendium (Gentleman and
Temple Lang 2007) structured as an RStudio project (Gandrud 2016) and are freely available for download at https://osf.io/23ghm.

\section{Results}

\section{Characterization of the survey and orchards}

During the 14-year period, the inspections covered 118 municipalities out of 196 municipalities with at least one registered commercial farm (as of 2019, Instituto Mineiro de Agropecuária 2020). Mandarins represented the highest number of inspected orchards (77.4\%) mainly grown in the South of Minas and Central MG. Although second in the number of orchards (19.21\%), the acreage cultivated with sweet orange is the largest among the citrus types, representing around two thirds of the total citrus area. Sweet orange production is highly concentrated in the Triângulo Mineiro (Table 1, Fig. 2).
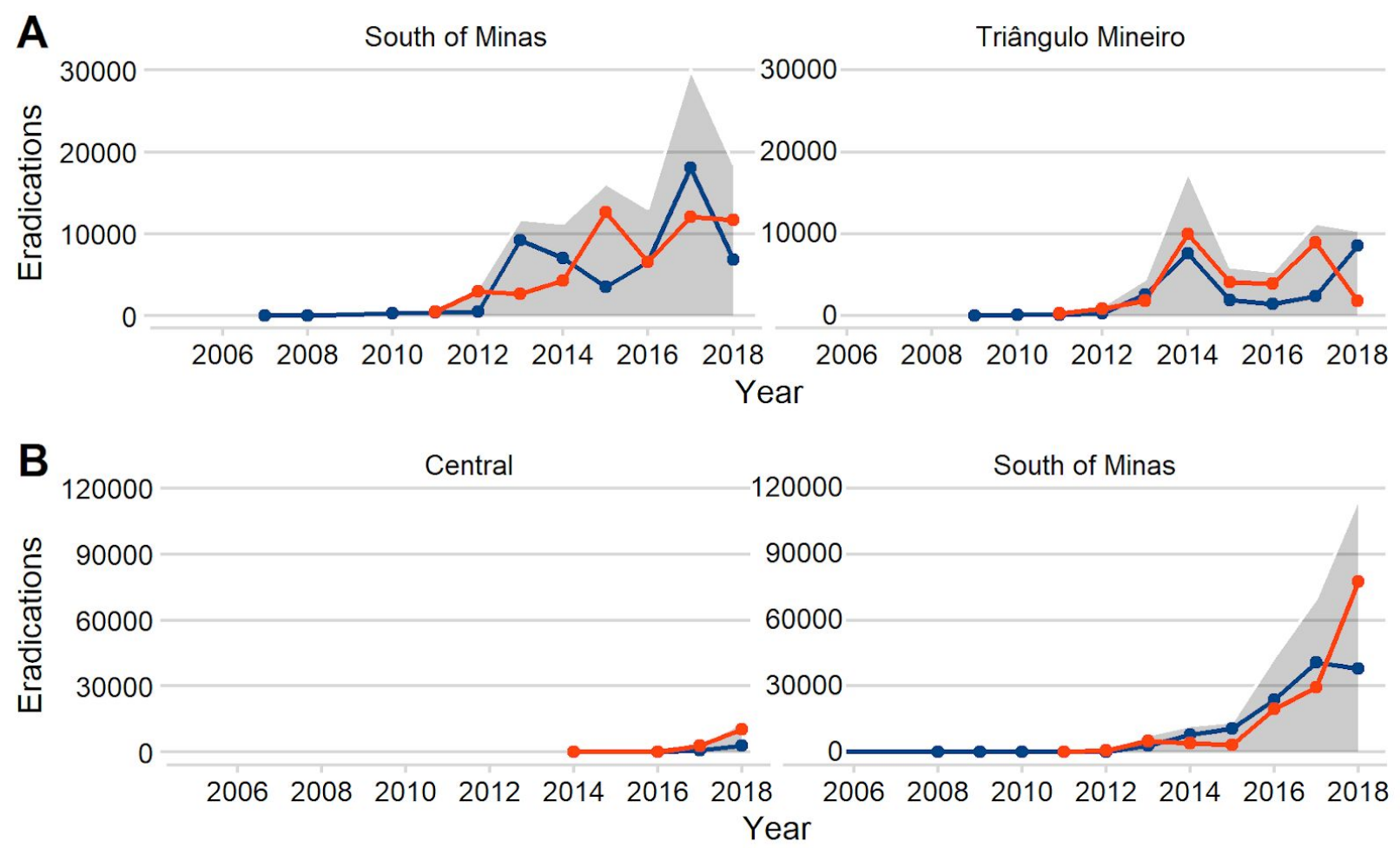

Semester $\bullet 1 \leftarrow 2$

Figure 4: Yearly totals (gray area) or by semester (dotted colored lines) of the numbers of removals of sweet orange (Citrus $\mathrm{x}$ cinensis) (A) and mandarins (Citrus reticulata) (B) plants due to the detection of huanglongbing conditioned production region within Minas Gerais State. See Figs. 2 and 5 for their locations in the map. 
The number of acid lime and lemon orchards were 55 (3.03\%) and $7(0.47 \%)$ respectively, all grown in the South of Minas and Triângulo Mineiro (Table 1). The size of the orchards was also quite distinct among the regions. Medium and large size orchards were concentrated in the Triângulo Mineiro, almost all of the sweet orange. More than half of the inspected orchards were mandarins of the mini size, which are largely predominant in the South of Minas and Central MG (Table 2).

\section{Current status of HLB occurrence and percent eradication}

HLB has been detected in more than half of the inspected orchards across the state up to 2018. These HLB-affected orchards represented $64 \%$ of municipalities where these orchards were located (Table 1, Fig. 2). The proportion of HLB-affected orchards was structured by region and citrus type. The lowest frequency of HLB in the two largely predominant citrus types (mandarin and sweet orange) was found in the Triângulo Mineiro. Percent
HLB-affected orchards ranging from $\sim 40$ to $80 \%$ were reported in the South of Minas and Central regions (Table 1). Lemon orchards were the least affected.

The overall mean percent HLB eradication in the orchard was rather low (1.78\%) and ranged from 0.02 to $10.51 \%$ across the regions and citrus varieties. Percent eradication as low as $2 \%$ was found in acid limes and $10.51 \%$ in the single lemon orchard. Eradication was generally low for sweet oranges, notably in the Triângulo Mineiro (0.36\%). The eradications in mandarins was $4.67 \%$, on average; ranged from $0.61 \%$ in the Central region to $~ 3 \%$ and $8 \%$ in the Triângulo Mineiro and South of Minas, respectively. The percent eradication due to HLB on mandarins was inversely related to the increase in orchard size, irrespectively of the region (South of Minas or Central), which in this case was mostly of the mini and small size. Such trend was not evident for sweet oranges (Figure 1).
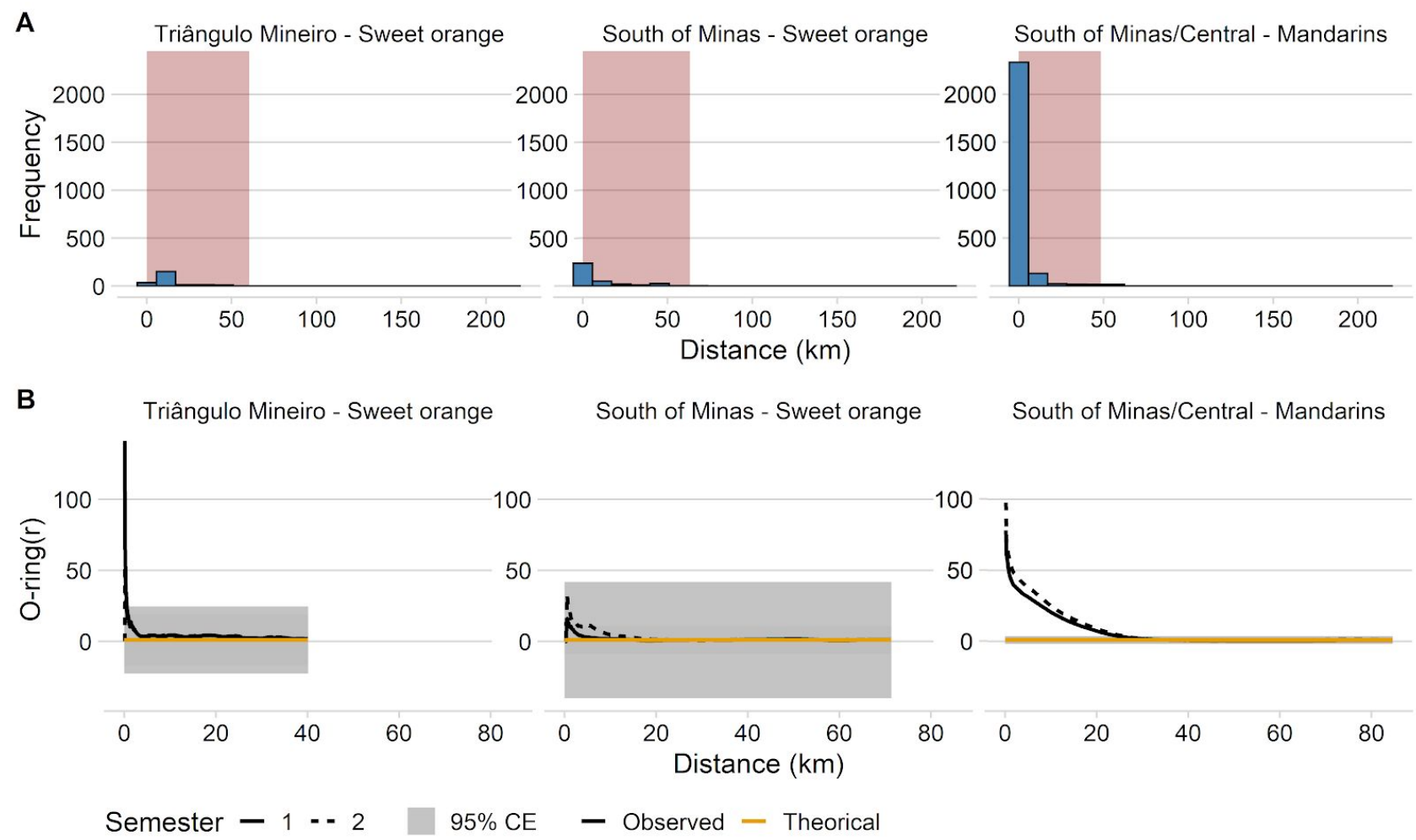

Figure 5: Frequency of the nearest neighbor distances (NNDs) (A) calculated yearly during 8 years (2010 to 2018) for each pair of orchards. Light-red shaded areas represent the interval in which contains the first $99 \%$ quantiles of the distributions. The O-ring statistics summarizes the spatial patterns of HLB (B) for three scenarios defined for combinations of citrus variety (sweet orange or mandarins) and citrus-producing regions in Minas Gerais States of Brazil (Triângulo Mineiro, South of Minas and South of Minas-Central). 


\section{Spatiotemporal HLB spread}

After the first detection in 2005, new cases were reported three years later (2008) and were limited to the same region in the South of Minas, closer to the original focus (Figure 2A). The first detection in the Triângulo Mineiro occurred in 2009, where sweet oranges dominate the scenario (Figure 2A). In the following year, 2010, another focus appeared in the southeastern and western areas of the state. The South of Minas/Central detections expanded considerably the epidemic extent to near $400 \mathrm{~km}$, in a logarithmic-like growth pattern (Figure 2C). The expansion rate calculated for South of Minas/Central was 25.7 $\mathrm{km} /$ year (95\% confidence interval: 14.7 to $36.7 \mathrm{~km} /$ year). However, in the Triângulo Mineiro, besides its slow progress at the early stages of the epidemics, disease extension increased considerably after the first five years (Figure 2C), boosting the expansion rate to $45.9 \mathrm{~km}$ /year (95\% confidence interval: 26.6 to $65.1 \mathrm{~km} /$ year). The spread of HLB to new orchards was slow during the first five years, up to 2010 (Figure 2B). The rate of affected orchards/year increased for mandarins while keeping at a constant rate for sweet oranges (Figure 2B).

\section{Percent HLB-affected orchards by region and orchard size}

Temporal progress curves of the number of HLB-affected orchards were plotted for the two major citrus species and conditioned to region (Figure 3). For sweet oranges, the disease has spread faster in the South of Minas than in the Triângulo Mineiro. In the South of Minas, $76 \%$ of the mini and small size orchards, regardless of the citrus variety (Table 1) were affected by the disease as of 2018.

For mandarins grown in the South of Minas and Central regions in mini and small size orchards, the rate of expansion into new areas has been much faster than the rate for sweet oranges. In the South of Minas, where the disease began spreading to new mandarin areas in 2011, the rate of new orchards/year was 67 for the 8 -year period. In the Central region, where the disease was found in 2014 in two orchards but started spreading in 2016, the rate was 61.3 orchards/year. The number of new cases almost doubled in 2018 compared to the previous year (Figure 3).

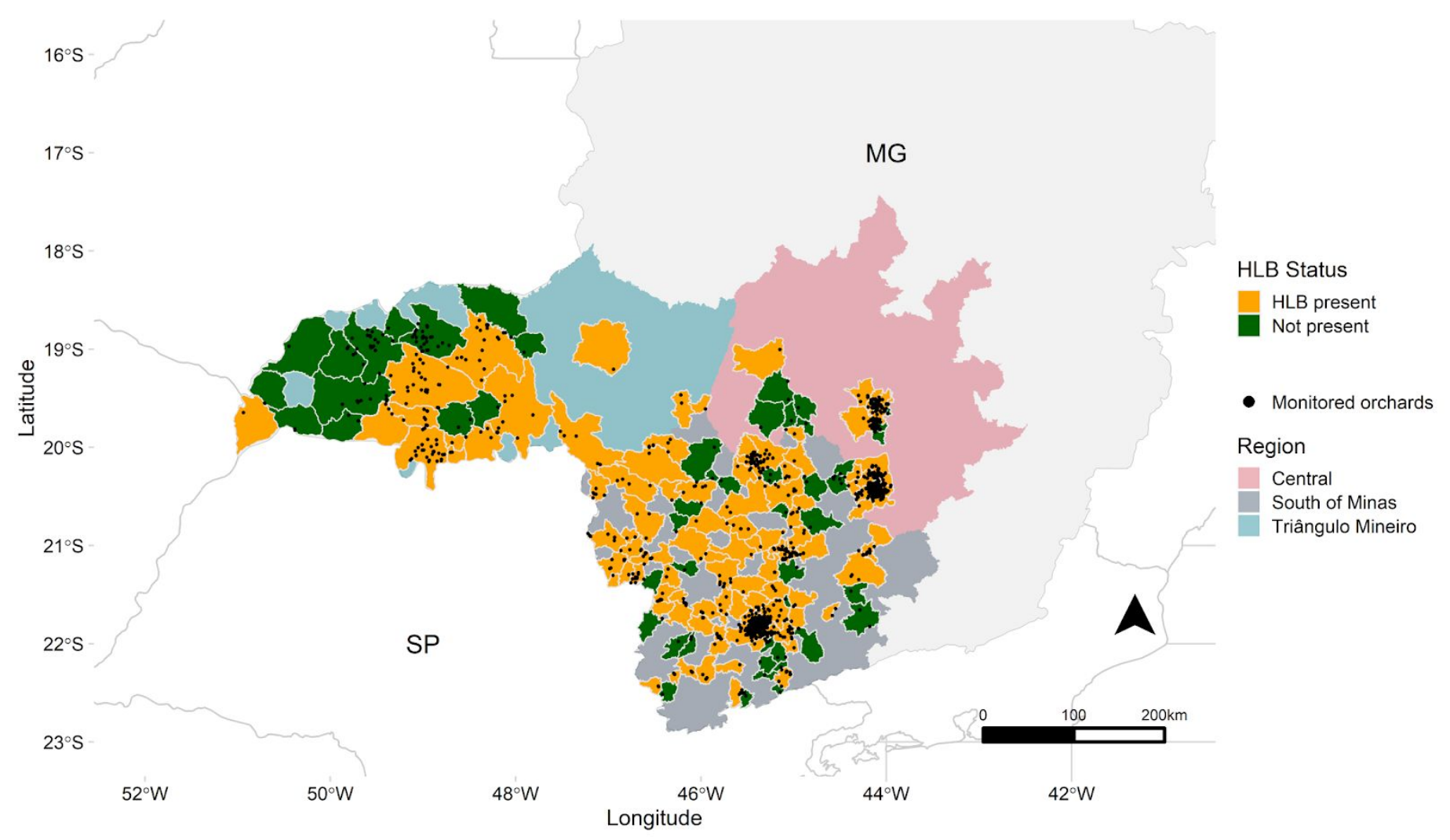

Figure 6: Geographic map of the Minas Gerais state, Brazil, depicting the approximate location of each of 1487 orchards (dots) of four citrus varieties (See table 2 for details) and the limits of inspected 118 citrus-producing municipalities colored by the status of huanglongbing occurrence as December 2018. Data collected by field inspectors and curated by the Instituto Mineiro de Agropecuária since 2005. 


\section{Eradications over time}

An overall increase in the number of eradications was observed in most situations, excepting sweet orange orchards in the Triângulo Mineiro, where the eradications have shown a constant trend after reaching $>15,000$ removals in 2014 (Figure 4A). For sweet oranges, the maximum number of eradicated plants was in 2017 in the South of Minas, with $\sim 30,000$ removals, a 2-fold increase compared with Triângulo Mineiro. For mandarins, the numbers are even higher in the South of Minas with $\sim 115,000$ removals in 2018. In the Central MG, the number of eradications is still lower ( $<200$ trees) compared with the other regions (Figure 4B). Overall, there was no consistent visual evidence across the years that the number of eradications was affected by the semester.

\section{Nearest Neighbor and 0-ring statistics}

The maximum nearest-neighbor distance (NND) was $262.4 \mathrm{~km}$. However, almost all NNDs (99\%) was less than $60.40 \mathrm{~km}$ for sweet orange in the Triângulo Mineiro, 63.22 $\mathrm{km}$ for sweet orange in the South of Minas, and $48.48 \mathrm{~km}$ for mandarins in both South of Minas and Central regions (Figure 5-A).

The O-ring statistics confirmed the aggregated pattern of the disease. A strong aggregation pattern was detected in mandarins in the South of Minas and Central regions as evidenced by the departure of the observed and theoretical O-ring curves up to $30 \mathrm{~km}$. Aggregation, although at a lower distance, was observed for the sweet orange in the Triângulo Mineiro. HLB did not show an aggregated pattern for sweet orange orchards in the South of Minas (Figure 5B, Figure 6).

\section{Discussion}

We provide here the first comprehensive summary of the citrus production characteristics in HLB-monitored orchards of MG state. Three scenarios could be determined based on the combination of citrus variety, geography and orchard size, and their characteristics seemed to have affected the spread of HLB both among and within the orchards.

One of the scenarios is sweet orange production in medium to large size orchards in the Triângulo Mineiro, largest citrus fruit production in MG. In fact, $80 \%$ of $\sim 1.259$ $M$ tons produced in MG in 2017 was of sweet orange, followed by mandarin (13\%) and lemon (7\%) (IBGE 2018). Two microregions within the Triângulo Mineiro account for almost half of all sweet oranges produced in the state. Most of these large farms are owned by companies from São Paulo state and aim at supplying the citrus juice industry.

Data from a recent survey conducted by Fundecitrus showed that the percent of symptomatic plants of HLB in the Triângulo Mineiro was lower than in any other sweet orange production region in SP. The low levels of the overall mean percent eradication $(0.30 \%)$ of sweet oranges trees in the Triângulo Mineiro reported in this study, as of 2018, although it cannot be directly comparable, was not so different from the mean incidence of symptomatic sweet orange $(0.58 \%)$ recently reported by growers from the same region (Fundecitrus 2019). The size of the orchard did not seem to have affected the incidence in our study. The Fundecitrus' report for MG sweet orange farms in the Triângulo Mineiro showed that HLB incidence increased from less than one to $10 \%$ in the smallest $(<21 \mathrm{ha})$ orchard size and oldest ( $>10$ year-old) orchards. Using data from all regions of the citrus belt, including Triângulo Mineiro, Fundecitrus data showed a clear trend of increasing HLB incidence with the decrease in orchard size and increase in plant age (Fundecitrus 2019). Collectively, these data suggest that the spread of HLB has been very limited in the Triângulo Mineiro over a decade since the disease has been found, being currently officially reported in only $20 \%$ of the inspected orchards.

The total area of sweet orange production in the South of Minas is more than $3 x$ smaller than in the Triângulo Mineiro and is largely dominated by mini and small orchards. Compared with the Triângulo Mineiro, the percent HLB-affected orchards and percent removals of plants increased by more than $3 x$. Such increase may be partially explained by the size of the orchard as suggested by previous studies on the spatial and temporal HLB dynamics (Lou et al. 2014; Gottwald 2010; Belasque Jr. 2010; Gasparoto et al., 2018). The first infections are usually detected at the edge of the orchards where psyllid activity is greatest at distances from 100-200 meters away from the edge (Boina et al., 2009; Sétamou \& Bertels, 2015; Gasparoto et al., 2018). As expected, the larger the orchard the lower the percent of HLB-infected plants, and vice-versa (Fundecitrus 2017; Gottwald et al., 2008; Gasparoto et al., 2018; Bassanezi et al. 2020). The large-size industry-owned orchards are intensively managed for controlling the psyllid, which is an important factor for successfully managing HLB and may help to explain the differences in the HLB spread between Triângulo Mineiro and South of Minas (Carli et al., 2018; Bassanezi et al. 2013).

Another factor likely driving the spread of HLB in sweet oranges in the South of Minas is the proximity to the major mandarin production region dominated by smallholders and where no specific measures are used to control HLB. In addition to the high costs associated with sequential insecticide spray that mandarin-producing farmers cannot afford, smallholders are generally resistant to plant removal, a measure that could help prevent disease spread at the cost of the short-term income. However, without coordinated efforts of eradication and insecticide 
sprays by all farmers in a wide region, HLB control and dissemination becomes quite an impossible task (Bassanezi et al. 2013; Bassanezi et al. 2000).

The current status of HLB in mandarins produced in the South of Minas, where $\sim 80 \%$ of the inspected orchards are affected and close to $10 \%$ of the plants have been removed, is worrisome. The recent spread to mandarins in the Central MG, a region that shares similarities with farming characteristics and management practices in the South of Minas further confirms this hypothesis. As of 2018, the disease affected $40 \%$ of the inspected orchards but the incidence was still lower than $1 \%$ possibly due to its recent introduction and spread that began three years earlier. If farming practices in the Central region do not change, the disease is likely to continue spreading to other orchards.

Seasonal weather is known to drive vector activity, transmission effectiveness, and latency period, which may contribute to explain differences in the rate of HLB spread across years and regions. Previous studies have suggested the role of rainfall, relative humidity, and temperature as drivers of the epidemics from field to region scale (Shimwela et al. 2018; Narouei-Khandan et al., 2016; Tomaseto et al., 2018; Gasparoto et al., 2012). The orange production area in the Triângulo Mineiro is located at the Cerrado biome where dry winters and wet summers prevail (Aw Koppen's classification; Koppen 1923; Alvares et al., 2013). Orchards in the South of Minas (Cwb Koppen's classification; Alvares et al., 2013) are grown in higher altitudes with lower temperatures and wetter summer than in the Triângulo Mineiro. The Central MG shares climatic characteristics with these two other regions. The progress curves of removals, conditioned to the semester of the year, did not reveal any possible influence of the season on the number of eradications, and other factors like management decisions may be of influence. However, these data, as used here, are not ideal for relating weather with eradications that should be studied by selecting orchards with longer time series of removals. Further modeling studies may contribute to increasing the understanding of weather effects on disease progress, especially for mandarins for which the data are scarce compared with sweet oranges.

Our results of the slow progress and limited spread of HLB during the first seven years should be interpreted with caution. Up to 2012, the official inspections have focused on HLB-affected orchards. The new cases (orchards) during that period originated from voluntary notices further confirmed and officially reported by IMA. Therefore, the estimates of disease progress and spatial spread are highly uncertain by that time, which explain the sharp shift in the curves after 2012 when the inspection methodology was changed.

The spatial extent of HLB epidemics has stabilized after 2015 when it reached the Central region. The average speed of the epidemic front calculated in this study $(56.2 \mathrm{~km}$ year $^{-1}$ ) was within the range of the estimates in a Mexican one-year study on the spatial gradients of HLB in several citrus types grown in the Yucatan province in 2010-2011. The authors estimated rates ranging from 2.6 to $6 \mathrm{~km}$ month $^{-1}$, equivalent to 31.2 to $72 \mathrm{~km} \mathrm{year}{ }^{-1}$, across four orchards (Flores-Sánchez et al. 2017). Our estimates and those of the Mexican study are generally higher than the epidemic front speed of HLB in Florida and in São Paulo State over the years since the first detection. In Florida, the estimates ranged from $17.9 \mathrm{~km} /$ year $\left(\mathrm{SE}=10.4 \mathrm{~km}_{\text {year }}{ }^{-1}\right)$ to $21.3 \mathrm{~km} /$ year $\left(\mathrm{SE}=13.5 \mathrm{~km}\right.$ year $^{-1}$ ) for two foci (Shimwela et al., 2018). In São Paulo, the HLB front was estimated to move at $19.3 \mathrm{~km}$ /year (Gottwald et al., 2007; Gottwald et al., 2010). These differences may be due to the level of management used by the farmers such as eradications combined with sequential insecticide sprays for vector control (Bassanezi et al. 2020; Graham et al. 2020).

In fact, considering that most of the mandarin orchards are family-owned with low to no input, HLB has spread to more than $80 \%$ of the orchards in the South of Minas and more than $40 \%$ in the central region in only four years. It may take only a few years for the incidence to increase at levels similar to the South of Minas or even higher than $10 \%$. Our spatial analyses suggested weak aggregation of HLB in sweet oranges and stronger aggregation in mandarins. The distances to nearest HLB-affected neighbor orchards were rather small in mandarins which can be due to the proximity of the orchards; three highly dense foci can be noticed in the South of Minas and central MG (Figure 6). The O-ring statistics, calculated separately for each semester, confirmed the spatial dependence of HLB-affected mandarins orchards within $25 \mathrm{~km}$ of distance, regardless of the semester. For sweet oranges, the slight increase in spatial dependence in the second semester may be due to higher activity of the vectors in the previous semester (summer and spring), which may contribute to the spread of HLB at lower distances. Studies have shown direct and indirect evidence of D. citri long-distance dispersals (Gottwald et al., 2007; Martini et al., 2013; Lewis-Rosenblum et al., 2015). For instance, based on the spatial distribution of milk protein-labeled insects, Lewis-Rosenblum et al., (2015) showed that HLB-vector could travel at least $2 \mathrm{~km}$ within 12 days. The magnitude of the spatial dependence that we estimated lies within the gradient range estimated in a study in Mexico, from $10 \mathrm{~km}$ to $82.6 \mathrm{~km}$, depending on the direction of the four transects (Flores-Sánchez et al., 2017).

In conclusion, our study summarizes the historical and current status of HLB in MG and provides new data and insights into the large scale HLB epidemiology that can be further explored as more data become available. The 
current scenario is worrisome especially for mandarin production in mini to small family-owned orchards where the necessary resources for managing the disease are not available. It is urgent that research and extension efforts and resources are mobilized to help citrus farms in South of Minas and Central MG to extend as much as possible the feasibility of the production via integrated management practices to protect plant health. The situation is so serious that mandarin farmers are starting to abandon orchards and look for alternative crops. In São Paulo State HLB has forced more than five thousand farms to shift to another crop or to merge together with other farms from 2007 to 2018 (Bassanezi et al., 2020). Finally, our results can be of value to further improve risk assessment of HLB spread should it be introduced to regions that share similarities with South of Minas and Central MG such as the major tangerine production in the eastern regions of Rio Grande do Sul state and for which only qualitative assessment was performed (Sulzbach et al. 2018).

\section{Acknowledgments}

This study was financed in part by the Coordenação de Aperfeiçoamento de Pessoal de Nível Superior (CAPES) Finance Code 001. The authors are thankful to the Programa de Pós-graduação em Fitopatologia of the Universidade Federal de Viçosa (UFV) and to the Mestrado Profissional em Defesa Sanitária Vegetal (UFV). We also would like to thank the Instituto Mineiro de Agropecuária for providing the data for this study firstly presented in a professional masters thesis defended by L.H.M.C. K.S.A. acknowledges the CAPES for providing a graduate scholarship. EMD is thankful to Conselho Nacional de Desenvolvimento Científico e Tecnológico (CNPq) for providing a research fellowship.

\section{Literature Cited}

Alvares CA, Stape JL, Sentelhas PC, Gonçalves JLM, Sparovek G (2013) Köppen's climate classification map for Brazil. Meteorologische Zeitschrift 22:711-728

Baddeley A, Rubak E, Turner R (2015) Spatial Point Patterns: Methodology and Applications with R. London: Chapman and Hall/CRC Press, $2015 . \quad$ URL http://www.crcpress.com/Spatial-Point-Patterns-Methodology -and-Applications-with-R/Baddeley-Rubak-Turner/97814822102 $00 /$

Bassanezi RB, Lopes SA, de Miranda MP, Wulff NA, Volpe HXL, Ayres AJ (2020) Overview of citrus huanglongbing spread and management strategies in Brazil. Tropical Plant Pathology $45: 251-264$

Bassanezi RB, Montesino LH, Gimenes-Fernandes N, Yamamoto PT, Gottwald TR, Amorim L, Bergamin Filho A (2013) Efficacy of Area-Wide Inoculum Reduction and Vector Control on Temporal Progress of Huanglongbing in Young Sweet Orange Plantings. Plant Disease 97:789-796
Bassanezi RB, Lopes SA, Júnior JB, Spósito MB, Yamamoto PT, Miranda MP, Teixeira DC, Wulff NA (2010) Epidemiologia do huanglongbing e suas implicações para o manejo da doença. Citrus Research \& Technology 31:11-23

Bassanezi RB, Busato LA, Amorim L, Gottwald TR (2005). Preliminary spatial pattern analysis of Huanglongbing in São Paulo, Brazil. In International Organization of Citrus Virologists Conference Proceedings (1957-2010) (Vol. 16, No. 16)

Belasque Jr J, Bergamin Filho A, Bassanezi RB, Barbosa JC, Fernandes NG, Yamamoto PT, Lopes SA, Machado MA, Leite Junior RP, Ayres AJ, Massari CA (2009) Base científica para a erradicação de plantas sintomáticas e assintomáticas de huanglongbing (HLB, greening) visando o controle efetivo da doença. Tropical Plant Pathology 34:137-145

Belasque Jr J, Bassanezi RB, Yamamoto PT, Ayres AJ, Tachibana A, Violante AR, Tank Jr A, Di Giorgi F, Tersi FEA, Menezes GM, Dragone J, Jank Jr RH, Bové JM (2010) Lessons from Huanglongbing management in São Paulo State, Brazil. Journal of Plant Pathology 92:285-302

Blaustein RA, Lorca GL, Teplitski M (2018) Challenges for managing Candidatus Liberibacter spp. (huanglongbing disease pathogen): current control measures and future directions. Phytopathology 108:424-435

Boina DR, Meyer WL, Onagbola EO, Stelinski LL (2009) Quantifying dispersal of Diaphorina citri (Hemiptera: Psyllidae) by immunomarking and potential impact of unmanaged groves on commercial citrus management. Environmental Entomology 38:1250-1258

Bové JM (2006) Huanglongbing: a destructive, newly-emerging, century-old disease of citrus. Journal of Plant Pathology 88:7-37

Cocuzza GEM, Alberto U, Hernández-Suárez E, Siverio F, Di Silvestro S, Tena A, Carmelo R (2017) A review on Trioza erytreae (African citrus psyllid), now in mainland Europe, and its potential risk as vector of huanglongbing (HLB) in citrus. Journal of Pest Science 90:1-17

Coletta-Filho HD, Carlos EF, Alves KCS, Pereira MAR, Boscariol-Camargo RL, de Souza AA, Machado MA (2010) In planta multiplication and graft transmission of 'Candidatus Liberibacter asiaticus' revealed by Real-Time PCR. European Journal of Plant Pathology 126:53-60

Coletta-Filho HD, Targon MLPN, Takita MA, De Negri JD, Pompeu JJ, Machado MA (2004) First report of the causal agent of huanglongbing ("Candidatus Liberibacter asiaticus") in Brazil. Plant Disease 88:1382

Carli LFD, Miranda MP, Volpe HXL, Zanardi OZ, Vizoni MC, Martini FM, Lopes JPA (2018) Leaf age affects the efficacy of insecticides to control Asian citrus psyllid, Diaphorina citri (Hemiptera: Liviidae). Journal of Applied Entomology142:689-695.

Craig AP, Cunniffe NJ, Parry M, Laranjeira FF, Gilligan CA (2018) Grower and regulator conflict in management of the citrus disease Huanglongbing in Brazil: A modelling study. Journal of Applied Ecology 55:1956-1965

da Graça JV, Douhan GW, Halbert SE, Keremane ML, Lee RF, Vidalakis G, Zhao H (2016) Huanglongbing: An overview of a complex pathosystem ravaging the world's citrus: Citrus huanglongbing. Journal of Integrative Plant Biology 58:373-387

Erpen L, Muniz FR, Moraes TS, Tavano ECR (2018) Análise do cultivo da laranja no Estado de São Paulo de 2001 a 2015. Revista IPecege 4:33-43

Flores-Sánchez JL, Mora-Aguilera G, Loeza-Kuk E, López-Arroyo JI, Gutiérrez-Espinosa MA, Velázquez-Monreal JJ, 
Domíngues-Monge S, Bassanezi RB, Acevedi-Sánchez G, Robles-Garcia P (2017) Diffusion model for describing the Regional Spread of Huanglongbing from First-Reported Outbreaks and Basing an Area Wide Disease Management Strategy. Plant Disease 101:1119-1127

Fundecitrus - Fundo de Defesa da Citricultura. Levantamento da incidência das doenças dos citros: Greening, CVC e Cancro cítrico / Fundo de Defesa da Citricultura. - Araraquara, SP: Fundecitrus, 2019. 55p.

Gasparoto MCG, Hau B, Bassanezi RB, Rodrigues JC, Amorim L (2018) Spatiotemporal dynamics of citrus huanglongbing spread: a case study. Plant Pathology 67:1621-1628

Gasparoto MCG, Coletta-Filho HD, Bassanezi RB, Lopes SA, Lourenço SA, Amorim L (2012) Influence of temperature on infection and establishment of 'Candidatus Liberibacter americanus' and 'Candidatus Liberibacter asiaticus' in citrus plants. Plant Pathology 61:658-664

Gentleman R, Temple Lang D (2007) Statistical analyses and reproducible research, Journal of Computational and Graphical Statistics 16:1-23.

Gottwald TR (2010) Current Epidemiological Understanding of Citrus Huanglongbing. Annual Review of Phytopathology 48:119-139.

Gottwald TR, Irey MS, Gast T, Parnell SR, Taylor E, Hilf M (2010) Spatio-temporal analysis of an HLB epidemic in Florida and implications for spread. In: International Organization of Citrus Virologists Conference Proceedings (1957-2010) (Vol. 17, No. 17).

Gottwald TR, Irey M, Gast T (2008) The plantation edge effect of HLB - a geostatistical analysis. In: International Research Conference on Huanglongbing Proceedings Orlando. pp. 305-308.

Gottwald TR, Graça JV, Bassanezi RB (2007) Citrus huanglongbing: the pathogen and its impact. Plant Health Progress. 8:31

Graham J, Gottwald T, Setamou M (2020) Status of huanglongbing (HLB) outbreaks in Florida, California and Texas. Tropical Plant Pathology 45:265-278.

Hall DG, Richardson ML, Ammar ED, Halbert SE (2013) Asian citrus psyllid, Diaphorina citri, vector of citrus huanglongbing disease. Entomologia Experimentalis et Applicata 146:207-223

Hall DG, Hentz MG (2011) Seasonal flight activity by the Asian citrus psyllid in east central Florida. Entomologia Experimentalis et Applicata 139: 75-85

Hodges AW, Spreen TH (2012) Economic impacts of citrus greening (HLB) in Florida: 2006/07-2010/11. Technical Report. Food and Resource Economics Department, Florida Cooperative Extension Service, Institute of Food and Agricultural Sciences, University of Florida.

Hu J, Jiang J, Wang N (2017) Control of citrus Huanglongbing via trunk injection of plant defense activators and antibiotics. Phytopathology 108:186-195

IBGE (2018) Levantamento sistemático de produção agrícola, LSPA, https://sidra.ibge.gov.br/pesquisa/lspa/referencias

Instituto Mineiro de Agropecuária - IMA. HLB/Greening - Available at: http://www.ima.mg.gov.br/sanidade-vegetal/hlb-greening [Accessed April 26, 2020].

Kassambara A, Mundt F (2017). factoextra: extract and visualize the results of multivariate data analyses. $\mathrm{R}$ package version 1.0.5. https://CRAN.R-project.org/package=factoextra.

Koppen W (1923) Dle Klirnate der Erde. Walter de Gruyter, Belin.
Kelley AJ, Pelz-Stelinski KS (2019) Effect of thermotherapy on the acquisition of Candidatus Liberibacter asiaticus by the Asian citrus psyllid (Hemiptera: Liviidae). Florida Entomologist 102:107-112

Le S, Josse J, Husson F (2008). FactoMineR: An R package for multivariate analysis. Journal of Statistical Software 25 1-18. 10.18637/jss.v025.i01

Lee JA, Halbert SE, Dawson WO, Robertson CJ, Keesling JE, Singer $\mathrm{BH}$ (2015) Asymptomatic spread of huanglongbing and implications for disease control. Proceedings of the National Academy of Sciences USA 112:7605-7610.

Leal RM, Barbosa JC, Costa MG, Belasque Jr J, Yamamoto PT, Dragone J (2010) Distribuição espacial de huanglongbing (greening) em citros utilizando a geoestatística. Revista Brasileira de Fruticultura 32:808-818

Lenth R (2019). emmeans: estimated marginal means, aka least-squares means. $\mathrm{R}$ package version 1.4.3.01. https://CRAN.R-project.org/package=emmeans

Lewis-Rosenblum H, Martini X, Tiwari S, Stelinski LL (2015) Seasonal Movement Patterns and Long-Range Dispersal of Asian Citrus Psyllid in Florida Citrus. Journal of Economic Entomology 108:3-10

Li J, Pang Z, Duan S, Lee, D, Kolbasov VG, Wang N (2019) The in planta effective concentration of oxytetracycline against 'Candidatus Liberibacter asiaticus' for suppression of citrus huanglongbing. Phytopathology 109:2046-2054

Lopes SA, Luis QB, Oliveira HT, Frare GF, Martins EC, Ayres AJ (2013) HLB research in Brazil - from etiology to disease management. Proceedings of the 19th Conference IOCV. pp. $47-50$.

Luo W, Anco DJ, Gottwald TR, Irey MS (2014) Edge Effects and Huanglongbing. Journal of Citrus Pathology 1. Online at: https://escholarship.org/uc/item/5hf0d0s3

Mendiburu F (2019). agricolae: Statistical Procedures for Agricultural Research. $\mathrm{R}$ package version 1.3-0. https://CRAN.R-project.org/package=agricolae.

Martini X, Addison T, Fleming B, Jackson I, Pelz-Stelinski K, Stelinski LL (2013) Occurrence of Diaphorina citri (Hemiptera: Liviidae) in an unexpected ecosystem: The lake Kissimmee state park forest, Florida. Florida Entomologist 96:658-660

Narouei-Khandan HA, Halbert SE, Worner SP, van Bruggen AHC (2016) Global climate suitability of citrus huanglongbing and its vector, the Asian citrus psyllid, using two correlative species distribution modeling approaches, with emphasis on the USA. European Journal of Plant Pathology 144:655-670

Ojiambo PS, Holmes GJ (2010) Spatiotemporal spread of cucurbit downy mildew in the Eastern United States. Phytopathology 101:451-461

Park JW, Louzada ES, Braswell WE, Stansly PA, Graça JV, McCollum G, Rascoe JE, Kunta M (2018) A new diagnostic real-time PCR method for huanglongbing detection in citrus root tissue. Journal of General Plant Pathology 84:359-367

Parnell S, Gottwald TR, Irey MS, Luo W, van den Bosch F (2011) A stochastic optimization method to estimate the spatial distribution of a pathogen from a sample. Phytopathology 101:1184-1190

Parry M, Gibson GJ, Parnell S, Gottwald TR, Irey MS, Gast TC, Gilligan CA (2014) Bayesian inference for an emerging arboreal epidemic in the presence of control. Proceedings of the National Academy of Sciences 111:6258-6262 
R Core Team (2018). R: A language and environment for statistical computing. $\mathrm{R}$ Foundation for Statistical Computing, Vienna, Austria. URL https://www.R-project.org/.

Richards FJ (1959) A flexible growth function for empirical use. Journal of Experimental Botany 10:290-300

Ruiz GJP, Júnior HJT, Sguarezi CN, Usberti R, Martello VP, Tomazela MS (2010). Ações de defesa sanitária vegetal no estado de São Paulo contra o huanglongbing. Citrus Research \& Technology 31:155-162

Sétamou M, Bartels DW (2015) Living on the edges: spatial niche occupation of Asian citrus psyllid, Diaphorina citri Kuwayama (Hemiptera: Liviidae), in citrus groves. PLoS ONE. 10:e0131917

Shen W, Halbert SE, Dickstein E, Manjunath KL, Shimwela MM, van Bruggen AHC. 2013. Occurrence and in-grove distribution of citrus huanglongbing in north central Florida. Journal of Plant Pathology 95:361-371

Shimwela MM, Schubert TS, Albritton M, Halbert SE, Jones DJ, Sun $\mathrm{X}$, Roberts PD, Singer BH, Lee WS, Jones JB, Ploetz RC, van Bruggen AHC (2018) Regional spatial-temporal spread of citrus huanglongbing is affected by rain in Florida. Phytopathology 108:1420-1428

Stansly PA, Arevalo HA, Qureshi JA, Jone MM, Hendricks K, Roberts PD, Roca FM (2014) Vector control and foliar nutrition to maintain economic sustainability of bearing citrus in Florida groves affected by huanglongbing. Pest Management Science 70:415-426

Sulzbach M, de Oliveira RP, Girardi EA, Bassanezi RB, Laranjeira FF, Schwarz SF (2018) Risk analysis of introduction and spread of huanglongbing in citrus groves in Rio Grande do Sul, Brazil. Tropical Plant Pathology 43:49-58

Tansey JA, Vanaclocha P, Monzo C, Jones M, Stansly PA (2017) Costs and benefits of insecticide and foliar nutrient applications to huanglongbing-infected citrus trees. Pest Management Science 73:904-916

Teixeira DC, Ayres J, Kitajima EW, Danet L, Jagoueix-Eveillard S, Saillard C, Bové JM (2005) First report of a huanglongbing-Like disease of citrus in Sao Paulo state, Brazil and association of a new Liberibacter species, "Candidatus Liberibacter americanus", with the disease. Plant Disease 89:107-107

Tomaseto AF, Miranda MP, Moral RA, de Lara IAR, Fereres A, Lopes JRS (2018) Environmental conditions for Diaphorina citri Kuwayama (Hemiptera: Liviidae) take-off. Journal of Applied Entomology 142:104-113

Vashisth T, Livingston $\mathrm{T}$ (2019) Assessment of pruning and controlled-release fertilizer to rejuvenate huanglongbing-affected sweet orange. HortTechnology. 29:933-940.

Wickham H (2016) ggplot2: Elegant graphics for data analysis. Springer-Verlag New York.

Wiegand T, Moloney KA (2004) Rings, circles, and null-models for point pattern analysis in ecology. Oikos 104:209-229

Wood SN (2017) Generalized Additive Models: An Introduction with $\mathrm{R}$ (2nd edition). Chapman and Hall/CRC.

Xie Y, Allaire JJ. Grolemund G (2018) R Markdown: The Definitive Guide. Chapman and Hall/CRC. ISBN 9781138359338. URL https://bookdown.org/yihui/rmarkdown.

Zhou C (2020) The Status of Citrus Huanglongbing in China. Tropical plant pathology 45:279-284 